\title{
GENERIC THEISTIC RELIABILISM
}

\section{FRANCIS JONBÄCK}

\author{
Uppsala University
}

\begin{abstract}
In this paper, I present the recently much discussed Value Challenge for Theories of Knowledge and formulate Generic Theistic Reliabilism as a theory, which can answer this challenge, with respect to Theism and the proposition 'God exists'.
\end{abstract}

\section{INTRODUCTION}

Recently, The Value Problem has provoked much attention in epistemology. ${ }^{1}$ In this paper (1) this problem is presented as a challenge for Theories of Knowledge, (2) Generic Theistic Reliabilism is formulated as a Theory of Knowledge which can answer the challenge, with respect to Theism and the proposition 'God exists' and (3) answers to two possible objections to the theory are offered. Theism is defined as follows:

Theism: The belief that (a) there is a person holding the title of being God, (b) God is morally perfect, all-knowing and almighty, and (c) God wants a loving relationship with all humans.

${ }^{1}$ See for instance Wayne Riggs, 'Reliability and the Value of Knowledge', Philosophy and Phenomenological Research, Vol. 64, No. 1 (2002), pp. 79-96; Wayne Riggs, 'The Value Turn in Epistemology' in Vincent Hendricks and Duncan Prichard (eds.), New Waves in Epistemology (London: Palgrave Macmillan, 2007), pp. 300-23; Ernest Sosa, 'The Place of Truth in Epistemology', in Michael DePaul and Linda Zagzebski (eds.), Intellectual Virtue Perspectives from Ethics and Epistemology (Oxford: Oxford UP, 2003), pp. 155-79; Jonathan Kvanvig, The Value of Knowledge and the Pursuit of Understanding (Cambridge: Cambridge UP, 2003); and John Greco, 'The Value Problem' in Adrian Haddock et al (eds.) Epistemic Value (Oxford: Oxford UP, 2009), pp. 313-21. 


\section{THE VALUE PROBLEM}

The Value Problem goes back to antiquity. John Greco writes:

In an often cited passage from Meno, Socrates points out that mere true belief seems to have the same practical value as knowledge - the man who truly believes that the road leads to Larissa is as well served as the man who knows that it does. The problem then is this: We think that knowledge has value over and above its practical value as useful information. How do we explain that extra value? This is something that a good theory of knowledge should do. ${ }^{2}$

In other words, true belief and knowledge seem to have the same instrumental or practical value, but yet, we think of knowledge as more valuable than true belief. Let us call Greco's challenge for Theories of Knowledge The Value Challenge and state it by posing the following question:

The Value Challenge: How do we explain why knowledge is more valuable than mere true belief?

Linda Zagzebski has argued that The Value Challenge is especially problematic to answer for various forms of Reliabilism. If we define Generic Reliabilism as follows:

Generic Reliabilism: A person S knows a proposition p if (a) S holds $\mathrm{p}$ as true, (b) p is true and (c) p is produced by one or more reliable processes or faculties ${ }^{3}$

Then we can formulate a rough version of her argument like this:

(1) Knowledge is more valuable than true belief

(2) Generic Reliabilism can only explain the value of true belief

(3) Therefore: Generic Reliabilism cannot explain the value of knowledge

Premise (1) is uncontroversial and widely accepted in literature. ${ }^{4}$ To vindicate premise (2) Zagzebski draws an analogy between reliably produced espresso and reliably produced true belief. She writes:

2 John Greco, 'The Value Problem', pp. 313-14.

${ }^{3}$ Obviously (a), (b), and (c) are not sufficient conditions for knowledge. At least a condition (d), which solves Gettier cases, is needed and if (c) doesn't answer the Value Challenge, a further condition (e), which answers The Value Challenge, is also needed.

${ }^{4}$ See for instance Linda Zagzebski, 'From Reliabilism to Virtue Epistemology' in Guy Axtell (ed.), Knowledge, Belief and Character (New York: Rowman and Littlefield, 2000), pp. 113-22; Linda Zagzebski, 'Epistemic Value Monism' in John Greco (ed.), Ernest Sosa 
[A] reliable espresso-maker is good because espresso is good, but the espresso made now is no better because it was produced by a reliable espresso machine. The Water dripping now is no better because it was produced by a reliable dripping faucet; and neither is it any worse. ${ }^{5}$

So, a good espresso, for example, seems to be equally good whether it is produced by a reliable espresso machine or luckily produced by an unreliable one.

Zagzebski continues the analogy:

[...] if Adam has a reliable memory and acquired a true belief about the past as a result of using his reliable memory, his belief is no more valuable epistemically than the true belief of Eva, who has an equally reliable memory and who acquired the same belief about the past, but acquired it by a non-reliable process. Eva may be no worse off than Adam, but the important point is that Adam is no better off than Eva. ${ }^{6}$

Put in another way, the source by which espresso is produced, or the source by which Adam's true belief is produced, does not add value to its products, namely the product of espresso or true belief. Put it in yet another way, a reliable espresso machine or a reliable memory might be good things to have, but the value of them does not accrue to the products they produce. Thus, we may conclude (3) Generic Reliabilism cannot explain the value of knowledge.

\section{AN ANSWER TO THE VALUE CHALLENGE}

Recently, epistemologists have answered The Value Challenge by shifting focus from the reliably produced true belief to the person producing it. A person who brings about the valuable product of true belief, they claim, is admirable for having so done. In other words, the person has made a creditable achievement. ${ }^{7}$ One way to answer The Value Challenge then is to appeal to what we might call The Achievement Thesis, which can be stated as follows:

and his Critics (Oxford: Blackwell, 2004), pp. 190-98; Wayne Riggs, 'Reliability and the Value of Knowledge'; Ernest Sosa, 'The Place of Truth in Epistemology'; and John Greco Achieving Knowledge (Cambridge: Cambridge UP, 2010), pp. 91-102.

${ }^{5}$ Linda Zagzebski, 'From Reliabilism to Virtue Epistemology', p. 113.

${ }^{6}$ Linda Zagzebski, 'From Reliabilism to Virtue Epistemology', p. 114.

7 John Greco, 'The Value Problem', Wayne Riggs, 'Reliability and the Value of Knowledge', Linda Zagzebski, 'From Reliabilism to Virtue Epistemology'. 
The Achievement Thesis: A person S' knowledge that $\mathrm{p}$ is an achievement creditable to $\mathrm{S}$.

Thus the extra value, besides the value of true belief, which explains the value of knowledge, is the value or 'admirability' of the person achieving knowledge.

The answer above is promising indeed, but turning to the domain of religion and particularly to knowledge of the proposition 'God exists' I have one suggestion:

Suggestion: The achievement, which serves to explain why knowledge is more valuable then true belief, is a moral rather than an epistemic one.

The achievements appealed to when answering The Value Challenge are usually epistemic. A person S might, for example, be very thorough and open-minded when reasoning, investigating, looking and so on. Achievements of this sort are admirable but they are epistemic achievements. However, with respect to Theism, I think the achievements might be purely moral ones. To show this, I will focus on condition (c) in our definition of Theism, namely the condition which states that God wants a loving relationship with all humans.

So God, by definition, wants a loving relationship with us. However, a loving relationship between God and us depends on love from both sides. Thus, a relationship with God and, as I will show, also knowledge of God makes demands on us.

One way to pin-point the demands God might have on us is to follow Apostle Paul's suggestion when he writes:

See to it that no one takes you captive through hollow and deceptive philosophy, which depends on human tradition and the basic principles of this world rather than on Christ. ${ }^{8}$

Apostle Paul might be interpreted as calling for a Christ Based Philosophy and, by implication, a Christ Based Epistemology. Generally, Jesus Christ is (at least by Christians) thought of as the paradigm example of a moral and obedient character and humans are called to follow him:

Then he called the crowd to him along with his disciples and said: 'Whoever wants to be my disciple must deny themselves and take up their cross and follow me. For whoever wants to save their life will lose it, but whoever loses their life for me and for the gospel will save it.'

${ }^{8}$ Colossians 2:8. 
Consequently, one demand for entering into a loving relationship with God might be that humans should shape their character by using Christ as a model. Another demand would be to follow Jesus' Divine Love Commandments, which say:

'Love the Lord your God with all your heart and with all your soul and with all your mind.' This is the first and greatest commandment. And the second is like it: 'Love your neighbour as yourself.' All the Law and the Prophets hang on these two commandments. ${ }^{10}$

Christian Philosopher Paul Moser comments on the implications of these 'great commandments':

These commands, found in the Hebrew scriptures and in the Christian New Testament, give a priority ranking to what humans should love. They imply that at the very top of a ranking of what we humans love should be, first, God and, second, our neighbor (as well as ourselves). They thus imply that any opposing ranking is morally unacceptable. More specifically, they imply that human projects, including intellectual and philosophical projects, are acceptable only to the extent that they contribute to satisfying the divine love commands. ${ }^{11}$

So one way, from our side, to be open to a loving relationship with God might be to give up our selfish ways, follow Jesus in every aspect of our life and love our neighbour. To do this would be to do something morally good.

If trying our best to be ready for a loving relationship with God by attaining a Christ shaped character and following Jesus' great commandments, one would expect that the God of Theism, that is a God who among other things actually wants a loving relationship with us, would induce in us the belief that he exists. Obviously, a loving relationship presupposes the belief that the one one loves exists. Moreover, the belief would count as knowledge, if the belief is true and induced in us in a reliable way, for example by means of a reliable process. Furthermore, in keeping with Generic Reliabilism as an Externalistic Theory of Knowledge, we do not need to know that the source or process, by which the true belief in God is produced, is reliable. All that is needed is that the process de facto is reliable. ${ }^{12}$

${ }^{9}$ Mark 8: 34-35. See e.g. also Matt 10:38-39 and Luke 9:23-24.

${ }^{10}$ Matthew 22:34-46.

${ }^{11}$ Paul Moser, Jesus and Philosophy (Cambridge: Cambridge UP, 2009), p. 14.

12 For a defence of externalism see e.g. Michael Bergmann, Justification Without Awareness (Oxford: Oxford UP, 2006). 
If we take ' $G$ ' to signify the proposition 'God exists' we can call this new Theory of Knowledge Generic Theistic Reliabilism and formulate it as follows:

Generic Theistic Reliabilism: A person S knows that G if (a) S holds G as true, (b) G is true, (c) G is produced in S, by God, by the means of one or more reliable processes or faculties and (d) G was produced in S, by God, because $S$ has made one or more moral achievements. ${ }^{13}$ Condition (d) answers The Value Challenge, but the moral achievements (d) alludes to, would also need to be sufficient for $\mathrm{S}$ to be ready for a loving relationship with God. Put in another way, God might withhold the belief that He exists from us until we achieved a moral character sufficient for a relationship with Him.

\section{A FIRST OBJECTION AND THE POSSIBILITY OF A MULTI-APPROACH TO KNOWLEDGE OF GOD}

There are at the very least two interesting objections to Generic Theistic Reliabilism. The first can be illustrated by the following case which I call The Box-case:

The Box-case: Joe has a sealed box with 7 coins in it and he is offering a prize of $\$ 1,000$ to anyone who can guess how many coins the box contains. There are four people guessing. (1) Sue guesses that there are 7 coins in the box. She believes there are 7 coins for no better reasons than that 7 is her lucky number. (2) Alice guesses 7 . She infers that there are 7 coins from shaking the box carefully. She is very dexterous and has acute hearing. (3) Ted too guesses that there are 7 coins, because Joe opened the box so he could look inside. Joe did this for Ted because Ted had recently saved a child from drowning while risking his own life. ${ }^{14}$

We are presented with the Value Problem for knowledge, since all three, including lucky Sue in (1), are rewarded with $\$ 1,000$.

${ }^{13}$ Of course, for a sufficient set of conditions, a further condition (e) which solves Gettier problems would also be needed. One way to formulate (e) would be to say that $G$ is true because $\mathrm{G}$ is produced in $\mathrm{S}$, by God, by the means of one or more reliable processes or faculties. See Greco's proposed solution of the Gettier Problem in John Greco 'Virtues in Epistemology' in Paul Moser (ed.), The Oxford Handbook of Epistemology (Oxford: Oxford University Press, 2002), pp. 287-315 (p. 311).

${ }^{14}$ A version of this example was suggested to me by Professor David Hunt, Whittier College, Whittier, USA. 
We may think of The Box-Case as analogous to a cases where 'Joe' is replaced by 'God' and the proposition 'There are 7 coins in the box' with the proposition 'God exists', since Joe has power to show what the box contains in the same sense as God (if he exists) has power to induce the belief that God exists in whoever He wants. Indeed Ted (3) in The Box-Case might be seen as analogous to a case where person $\mathrm{S}$ has formed a Christ-shaped moral character sufficient for a loving relationship with God.

The following question presents itself: How is the knowledge in (3) more valuable than in (2)? Since there is nothing valuable in guessing something which by luck happens to be true, the belief in (1) cannot qualify as knowledge. On the other hand, the belief in (2) might be thought of as a fairly obvious example of knowledge, since Alice has attained her true belief in a praiseworthy and intrinsically valuable manner.

However, I do not necessarily think that Generic Theistic Reliabilism is the only Theistic Theory of Knowledge in town. God might be in a position to lay out different roads for us to attain knowledge of his existence just as Joe is in a position to lay out different roads for people to attain knowledge of how many coins the sealed box contains. In other words, there might be different approaches to gain knowledge with respect to the proposition 'God exists' and perhaps, as the box-case shows, something similar might be true for other propositions as well. Perchance, there is even a multitude of approaches. With respect to the proposition 'God exists', we might simply call the type of knowledge attained in accordance with (2) Virtue Epistemic Knowledge, and the type of knowledge attained in accordance with (3) Theistic Reliabilistic Knowledge.

\section{A SECOND OBJECTION AND THE SCEPTICAL THEISTS' RESPONSE}

The second objection consists of the recognition that there are loving (say) saint-like people in non-theistic religions. These people do not, as one perhaps would expect, find themselves with the belief that the theistic God exists, even though they might seem to be ready for loving relationship with God.

However, even if a person $S$ would seem to be ready for a loving relationship with God, God might have other to us unknown reasons for not inducing the belief that God exists in S. 
Given that God is all-knowing and almighty and we are not, it seems odd indeed to suggest that we can know all possible reasons God might have for withholding his existence from us. To be sure, one reason might be to wait until we are ready for a loving relationship with Him, but there might be other reasons as well.

This response is in line with the position known as Sceptical Theism. Advocators for Sceptical Theism do not only hold Theism to be true, they also hold a form of local scepticism to be true. Sceptical theist Michael Bergmann describes the sceptical part of Sceptical Theism by presenting the following four Sceptical Theses (ST):

ST1: We have no good reason for thinking that the possible goods we know of are representative of the possible goods there are.

ST2: We have no good reason for thinking that the possible evils we know of are representative of the possible evils there are.

ST3: We have no good reason for thinking that the entailment relations we know of between possible goods and possible evils are representative of the entailment relations there are between possible goods and of possible evils.

ST4: We have no good reason for thinking that the total moral value or disvalue we perceive in certain complex states of affairs accurately reflects the total moral value or disvaluethey really have. ${ }^{15}$

ST1-ST4 are to my mind sensible to hold as true, since it seems difficult indeed to think of a reason suggesting that we know all possible goods, possible evils, all logical connections between all possible goods and all possible evils, as well as the real value of all possible goods and all possible evils. Furthermore, if ST1-ST4 are true, it follows that there might be a person $\mathrm{S}$ and a possible good X such as X would not be possible if God induced the belief that He exists in S, even if $S$ now has a moral character sufficient for a loving relationship with God.

A contra argument to the forgoing sceptical response might be that if we cannot know if there is a good X that might justify God in withholding His existence to a person $\mathrm{S}$, who seems to be ready for a relationship with Him, we cannot know if we should try to convince $S$ that God exists.

${ }^{15}$ Michael Bergmann, 'Commonsense Skeptical Theism', in Reason, Metaphysics, and Mind: New Essays on the Philosophy of Alvin Plantinga, ed. Kelly James Clark and Michael C. Rea (New York: Oxford University Press, 2012), pp. 9-30 (pp. 11-12). 
Briefly, if we try to convince S that God exists, a possible good X might be lost.

Indeed, it seems problematic to use Sceptical Theism in order to defend Generic Theistic Reliabilism, if it is the case that we cannot decide whether or not we should try to convince other people that God exists. However, in every day cases when we are not certain whether or not there might be a reason for not intervening when (say) suffering occurs, we usually act on the possibility of us actually preventing it if we intervene. In other words we act on the reasons we currently have for intervening. Justin McBrayer and Philip Swenson apply this line of reasoning from ignorance to a case where one might be able to convince someone that God exists. Someone, they claim, could deliberate as follows:

I am not sure whether or not there is a sufficient reason to allow this person to be ignorant of God's existence. But since I am not sure, it is an open possibility that I will prevent an unjustified evil from occurring. So I have reason to inform her. ${ }^{16}$

A somewhat similar answer is to deny a version of what we might call the Consequentialist Criterion. This criterion, when considering rational and responsible reasoning, can be formulated as follows:

The Consequentialist Criterion: A person S's decision or line of reasoning, regarding an act, is rationally appropriate if all possible consequences of the act are taken into consideration.

Endorsing this criterion would be (a) to set the standard of rational reasoning too high and it is (b) not at all consistent with Sceptical Theism. A better, more apt, criterion would be the following:

The Consequentialist Criterion*: A person S's decision or line of reasoning, regarding an act, is rationally appropriate if all possible consequences $\mathrm{S}$ can reasonably predict are taken into consideration.

Of course God would perhaps meet The Consequentialist Criterion since he might know all possible goods and evils and thus be able to predict all possible outcomes, but given our cognitive limitations The Consequentialist Criterion ${ }^{*}$ seems more fitting to us humans. To put this in another way, how high standards we have on rational and responsible reasoning is a function of our cognitive abilities.

${ }^{16}$ Justin McBrayer and Philip Swenson, 'Scepticism About the Argument from Divine Hiddenness', Religious Studies, 48 (2012), 129-50 (p. 146). 
To sum up, we can answer The Value Challenge for Theories of Knowledge by adopting Generic Theistic Reliabilism. Moreover, we can answer the objection explicated by The Box-case by adopting a Multiapproach to Knowledge. Also, we have an answer to the objection that there are people in the world who seem to be ready for a relationship with God, but yet do not believe that God exists by adopting Sceptical Theism. 